\title{
NECROLÓGIO
}

\section{KENNETH S. WARREN}

Em 18 de setembro do ano passado faleceu no Estado de New York, USA, o Dr. Kenneth S. Warren. Um proeminente pesquisador na área de Medicina Tropical, tendo feito contribuições fundamentais no campo da esquistossomose, o Dr. Warren trabalhou no Brasil (Salvador, Bahia) durante dois anos seguidos (1961-1963), tendo depois feito várias visitas curtas a este país. Participou da fundação da Sociedade Brasileira de Medicina Tropical (reunião de Ribeirão Preto) e fez muitos amigos e admiradores entre os pesquisadores brasileiros.

Foi um pioneiro em demonstrar, com o modelo da esquistossomose hepatoesplênica humana, que um defeito hepato-celular e não a circulação colateral era o fator primordial no desencadeamento do coma hepático. Seus estudos sobre a modulação do granuloma esquistossomótico e a participação de imunidade celular nas lesões esquistossomóticas, são hoje clássicos.

Da sua base em Cleveland (Case Western Reserve University School of Medicine), onde trabalhou de 1963 a 1977, o Dr. Warren realizou, estimulou e colaborou em projetos de pesquisas em várias partes do mundo, incluindo o Brasil, a ilha de Santa Lúcia, Kenia, Filipinas etc. Este papel de incentivador dos estudos sobre Medicina Tropical foi brilhantemente continuado e ampliado quando ele entrou para a Fundação Rockfeller (1977-1988) e criou um programa de fomento à pesquisa em doenças infectuosas e parasitárias sugestivamente denominado "Great Neglected Diseases of Mankind".

Entre 1989 e 1992 ele foi contratado por uma editora (Maxweell Communications Corporation) e se dedicou a um programa informatizado para bibliotecas médicas em todo o mundo, para facilitar o acesso à informação contida nas publicações científicas.

Nos últimos anos, o Dr. Warren vinha prestando sua colaboração como Vice-Presidente do Instituto Picower, um centro beneficente não-governamental para a pesquisa científica.

Dr. Warren atuou como Editor de importantes publicações sobre doenças parasitárias, educação médica e medicina social. Em tudo o que fazia apareciam as suas características de trabalhador dedicado, meticuloso, entusiasta, estimulante e inovador.

Os seus amigos brasileiros sentiram muito a sua morte. Durante o XXXIII Congresso da Sociedade Brasileira de Medicina Tropical, realizado em fevereiro último em Belo Horizonte, MG, a Assembléia Geral aprovou um voto de pesar pelo passamento do Dr. Kenneth S. Warren. 